\title{
Phytochemical, antibacterial and antifungal activities of leaves and bark of Colebrookea oppositifolia: an ethnomedicinal plant
}

\author{
Muhammad Ajaib ${ }^{1 *}$, Samia Abid ${ }^{1}$, Musfirah Anjum ${ }^{1}$, Qumqum \\ Noshad $^{1}$, Muhammad Faheem Siddiqui ${ }^{2}$ and Muhammad Asif Iqbal ${ }^{3}$ \\ 1. Department of Botany, Mirpur University of Science and Technology (MUST), Mirpur-10250 (AJK)- \\ Pakistan \\ 2. Department of Botany, University of Karachi, Karachi 75270-Pakistan \\ 3. Department of Chemistry, University of Management and Technology (UMT), Lahore-Pakistan \\ *Corresponding author's email: majaibchaudhry@yahoo.com
}

Citation

Muhammad Ajaib, Samia Abid, Musfirah Anjum, Qumqum Noshad, Muhammad Faheem Siddiqui and Muhammad Asif Iqbal. Phytochemical, antibacterial and antifungal activities of leaves and bark of Colebrookea oppositifolia: an ethnomedicinal plant. Pure and Applied Biology. Vol. 7, Issue 1, pp138-151.

http://dx.doi.org/10.19045/bspab.2018.70017

Received: 21/10/2017 Revised: 05/01/2018

Accepted: 05/01/2018

Online First: 17/01/2018

\section{Abstract}

The phytochemical, antibacterial, antifungal and MIC (minimum inhibitory concentration) study of the leaves and bark of Colebrookea oppositifolia Smith was evaluated. Phytochemical screening C. oppositifolia Sm. indicated the presence of alkaloids, flavonoids, glycosides, steroids and saponins whereas terpenoids, tannins, and cardiac glycosides are showed only in bark extract. Petroleum ether extract showed maximum effectiveness against $P$. aeruginosa with bark extract $(18 \pm 2.2 \mathrm{~mm})$ and maximum antifungal potential exhibited by petroleum ether extract of leaves $(15 \pm 0.3 \mathrm{~mm})$ against $A$. nigar. It was noticed that the extracts in distilled water had not shown much potential. The MIC assay was carried out for further verification of results obtained by the Zone of Inhibition against both bacterial and fungal strains. The lowest MIC value is $0.09 \pm 0.3$ at $1 \mathrm{mg} / \mathrm{mL}$ against $E$. coli exhibited by bark extract and $0.09 \pm 0.2$ at 0.9 $\mathrm{mg} / \mathrm{mL}$ against $K$. pneumoniae shown by leaf extract. Whereas, in fungi minimal MIC value exhibited $0.11 \pm 0.3$ at $0.9 \mathrm{mg} / \mathrm{mL}$ by leaf extract against $A$. oryzae. Hence, it is recommended further investigation to explore toxicological and clinical trials before using this plant as drug. Keywords: Antibacterial; Antifungal;Colebrookea oppositifolia; Ethnomedicinal plant

\section{Introduction}

Products obtained from plants have been used medicinal purposes since pre-historic time. For instance, certain conventional pharmaceuticals including numerous trees, bushes, climbers and herbs have been utilized to remedy of certain diseases. Traditionally important plants have become sources for examining their bioactive properties by the identification of a critical number of helpful compounds $[1,2]$. Ethno-botanical plants frequently use as pharmaceuticals, Nutraceuticals, makeup and nourishment supplements [3]. With an expansion of resistant microorganisms, conventional plants are being researched for their antibacterial and therapeutic qualities. The antibacterial and antifungal impact of a plant is because of the 
phytochemicals such as saponins, phenolic compounds, tannins, terpernoids, heart glycosides, alkaloids and flavonoids [4]. Numerous emphasis made on deciding the antimicrobial action of plant concentrates found in local societies in the form of oils, flavonoids, alkaloids, lactones etc.[5].

Foodborne diseases fall out 76 million individuals every year in the United States, represent almost 325,000 hospitalizations and more than 5,000 passings. The diseases caused by food are generally dangerous, even fatal for example, microscopic organisms, growths, infections and parasites that enter the body essentially by the ingestion of debased sustenance [6]. Because of the rapid resistance to antibiotics by using allopathic medicines, there is a need to grow new and inventive antimicrobial compounds. As plants are cheap, non-poisonous source, there is a long convention of utilizing them as a part of the treatment of irresistible illness in Cameroonian people[7]. There are numerous strategies for hindering or inactivating microorganisms by utilizing plant derived products as antimicrobials [8].

Colebrookea oppositifolia Smith (Figure1) is a genus of family Lamiaceae/Labiateae. C. oppositifolia is commonly known as Bansa.It is medicinally important plant and it is utilized locally as sickness for differentpurposes. The leaves paste is utilized for wound healing and bruises while the paste of its roots is utilized against the epilepsy [9]. Juice assimilated by beating young leaves is utilized as anthelmintic [10]. The root and stem juice are used in eye diseases. It has intriguing antibacterial action and had exceptional radical searching potential to be utilized as cell reinforcement [11]. Keeping in view the significance of ethno botanical status of C. oppositifoliaSmith and other members of family Lamiaceae the present investigation was carried out.

Materials and methods

Plant material
The plant Colebrookeaoppositifolia Sm. commonly known as Bansa Siyah was collected from the Kakra town, District Mirpur AJK. Some plants of that species also seen in Khoirata, Peer Gali and Kotli. This plant belongs to the family Lamiaceae, also called as Mint family. The plant species collected was mounted on herbarium sheet and submitted in the Herbarium Department of Botany MUST, Bhimber campus. A voucher No. MUST.

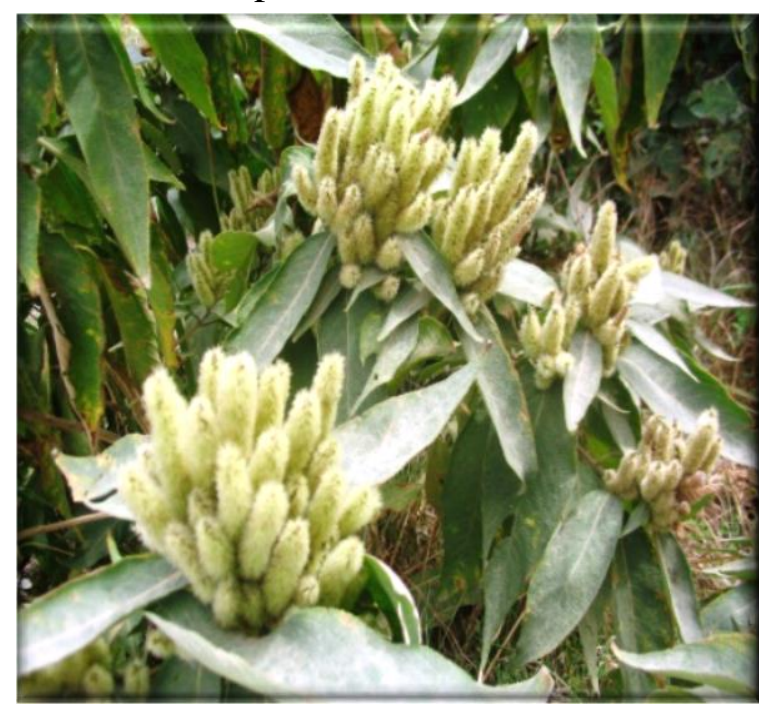

BOT. 880 to obtain for further reference.

\section{Figure 1. Colebrookea oppositifolia Test organisms}

Total six bacteria were selected, the three strains were from gram

positiveEnterococcus

faecalis,Staphylococcus aureus and Bacillus subtilis and two strains of gram negativeKlebsiellapneumonia,Escherichia coli and Pseudomonas aeruginosaand two strains of fungal i.e. Aspergillus oryzae and Aspergillusnigerwere selected used for investigation of antimicrobial perspective of C. oppositifolia Smith. Four standard antibiotics of bacterial strains (azithromycin, methicillin, amoxicillin and ampicillin) and four standard antibiotics of fungal strains (nystatin, tezole, fungivin, and griseofulvin) were tested for comparing the potential of plant extract with them.

\section{Methodology adopted}

The whole plant was washed with cold water for removing of mud. After washing the plant parts such as bark and leaves were 
separated and kept for drying under room temperature about 20-30 days. After drying the powder was made with the help of pestle and mortar and then exposed for maceration method [12].

\section{Maceration of the plant specimen}

The shade dried plant material of $C$. oppositifolia was subjected for maceration different solvents i.e. Petroleum ether,
Chloroform, Methanol and distilled water and then evaporated to get final concentrated form of extracts. Thecorporeal analysis of herbal extracts considered its texture, colour and appearance, and calculated yield before further study was accompanied.

Yields percentage (\%) was calculated with the following method:

$$
\text { Extraction yield }=\frac{\text { Weight of plant extract }}{\text { Weight of initial plant sample }} \times 100
$$

\section{Qualitative study of phytoconstituents}

The phytochemical investigation of plant extracts were done by using typical process [13].

\section{Estimation of antimicrobial activity}

By using agar well diffusion method for the antimicrobial activity of leaf and bark extracts of $C$. oppositifolia. For antibacterial activity methodology of [14] was used. For the bacterial strains i.e., $P$. aeruginosa,K. pneumonia, E.faecalis, $S$. aureus, B. subtilis and E.coli, the nutrient agar media was used. For antifungal activity the methodology of [15] was used. Potato Dextrose Agar media was used for antifungal activity.

Assessment of minimum inhibitory concentration (MIC)

Plant extracts of $C$. oppositifolia for MIC was investigated by broth-dilution method adapted by [16].

\section{Statistical Analysis}

Allthe statistical analysis was done utilizing Microsoft excel 2010.

\section{Results and discussion}

To checked the antimicrobial activity of the plant material i.e. Colebrookea oppositifolia Smith, extracts were prepared. Macerated and their \% yield was intended before further analysis, to provide glance of the economical perspective of the completepractice.The phytochemical screening the plant extracts of $C$. oppositifolia Smith was also achieved. Results showed the presence and absence of secondary metabolites (Table $1 \& 2$ ).

\section{Phytochemical recognition key}

$-=$ Absent, $+=$ Present in minimal quantity, $++=$ Existing in moderate quantity whereas, $+++=$ Present in noticeableamount. Six bacterial strains including three gram-positive (Staphylococcus aureus, Bacillus subtilis, Enterococcus facealis) and three gram negative (Escherichia coli, Pseudomonas aeruginosa, Klebsiella pneumoniae) were used for the estimation of antimicrobial activity of bark and fruit of Cholebrookia oppositifolia Smith. All of these bacteria were pathogenic. Furthermore, strains of fungal i.e.,A.oryzaeandA. niger, selected for antifungal prospective.

We also used some standard discs, to find out the receptiveness of the microbial strains. Which is used as the test organisms (Tables 3 \& 4). According to these standards, the specimens were categorized as vulnerable, transitional, and resistant prone. Leaf and bark of C.oppositifoliaproducediffrent Zone of Inhibition in response of bacterial strains was recorded in $\mathrm{mm}$. Zone of Inhibition was produced by the $\mathrm{p}$. ether extract of leaf showed maximum results i.e. $18 \pm 0.6 \mathrm{~mm}$ against $B$. subtilis. Whereas, bark extract in p. ether showed maximum Zone of Inhibition i.e. $18 \pm 0.8 \mathrm{~mm}$ against $S$. aureusand $18 \pm 2.2 \mathrm{~mm}$ against $P$. aeruginosa. The leaf of C.oppositifolia Smith had displayed activity under the range of $0 \pm 0 \mathrm{~mm}$ to $18 \pm 0.6 \mathrm{~mm}$. Bark had exhibited the potential under the range of $0 \pm 0 \mathrm{~mm}$ to $18 \pm 2.2 \mathrm{~mm}$. 
Table 1. Phytochemical evaluations of Bark extracts of $C$. oppositifolia Smith

\begin{tabular}{|c|c|c|c|c|c|c|c|c|c|}
\hline \multirow{2}{*}{$\begin{array}{c}\text { Plant } \\
\text { Part }\end{array}$} & Solvent & Alkaloids & Steroids & Tannins & Flavonoids & Glycosides & Terpenoids & $\begin{array}{c}\text { Cardiac } \\
\text { Glycosides }\end{array}$ & Saponens \\
\hline & P. Ether & ++ & - & - & - & - & + & + & +++ \\
\cline { 2 - 11 } & Chloroform & + & + & - & ++ & - & +++ & + & ++ \\
\cline { 2 - 10 } & Methanol & +++ & ++ & + & - & + & + & - & - \\
\cline { 2 - 11 } & Aqueous & - & - & + & + & - & - & - & - \\
\hline
\end{tabular}

Table 2. Phytochemical evaluations of Leaves extract of $C$. oppositifolia Smith

\begin{tabular}{|c|c|c|c|c|c|c|c|c|c|}
\hline \multirow{3}{*}{$\begin{array}{c}\text { Plant } \\
\text { Part }\end{array}$} & Solvent & Alkaloids & Steroids & Tannins & Flavonoids & Glycosides & Terpenoids & $\begin{array}{c}\text { Cardiac } \\
\text { Glycosides }\end{array}$ & Saponens \\
\hline & P. Ether & +++ & + & - & + & + & - & - & ++ \\
\cline { 2 - 10 } & Chloroform & + & ++ & - & - & + & - & - & + \\
\cline { 2 - 10 } & Methanol & ++ & + & - & - & ++ & - & - & + \\
\cline { 2 - 11 } & Aqueous & - & - & - & + & - & - & - & - \\
\hline
\end{tabular}

Table 3. Zone of Inhibition (mm) produced by the bacterial strainsagainst standard antibiotic dises

\begin{tabular}{|c|c|c|c|c|c|c|c|}
\hline \multirow{2}{*}{$\begin{array}{c}\text { Antibiotic } \\
\text { standard disc }\end{array}$} & \multirow{2}{*}{$\begin{array}{c}\text { Conc } \\
(\boldsymbol{\mu g})\end{array}$} & $\begin{array}{c}\text { S. } \\
\text { aureus }\end{array}$ & E. coli & P. aeruginosa & K. pneumoniae & E. faecalis & B. subtilis \\
\hline Methicillin & 15 & $8 \pm 0.6$ & $9 \pm 1.2$ & $9 \pm 0.5$ & $8 \pm 0.5$ & $8 \pm 0.7$ & $8 \pm 0.5$ \\
\hline Amoxicillin & 30 & $8 \pm 1.5$ & $9 \pm 1.0$ & $8 \pm 1.0$ & $9 \pm 1.3$ & - & $11 \pm 1.0$ \\
\hline Azithromycin & 16 & $14 \pm 2.6$ & $14 \pm 1.3$ & $10.5 \pm 0.7$ & $11 \pm 0.5$ & $10 \pm 1.5$ & $12 \pm 1.5$ \\
\hline Ampicillin & 10 & $9 \pm 1.7$ & $8 \pm 2.0$ & $9 \pm 1.2$ & $8 \pm 1.0$ & $7 \pm 0.5$ & $8 \pm 0.5$ \\
\hline \multicolumn{2}{|c|}{ GeneralResponse } & Resistant & Resistant & Resistant & Resistant & Resistant & Resistant \\
\hline
\end{tabular}

Table 4. Zone of Inhibition (mm) of fungal strains against the standard antifungal discs

\begin{tabular}{|c|c|c|c|}
\hline \multirow{2}{*}{ Antifungal standard disc } & \multirow{2}{*}{$\begin{array}{c}\text { Concentration } \\
(\boldsymbol{\mu} \mathbf{g} / \mathbf{m l})\end{array}$} & \multicolumn{2}{|c|}{ Zone of inhibition $(\mathbf{m m})$} \\
\cline { 3 - 4 } & 99.9 & $23 \pm 2.1$ & A.oryzae \\
\hline Nystatin & 99.9 & $23 \pm 0.6$ & $30 \pm 1.6$ \\
\hline Tezole & 99.9 & $16 \pm 3.5$ & $67 \pm 2.6$ \\
\hline Fungivin & & Intermediate & $40 \pm 1.8$ \\
\hline \multicolumn{2}{|c|}{ General Response } &
\end{tabular}


The extract of leaf had showed supreme potential in contrast to $S$. Aureusas compared to the bark with the petroleum ether and aqueous, as shown in (Figure 2). Whereas, chloroform extracts of leaf and bark, mutually had displayed nearly muchalike potential with little difference. The potential exhibited by both parts was better as compared to standard discs. Theleast potency was showed by the methanolic extracts of both parts (Table5).

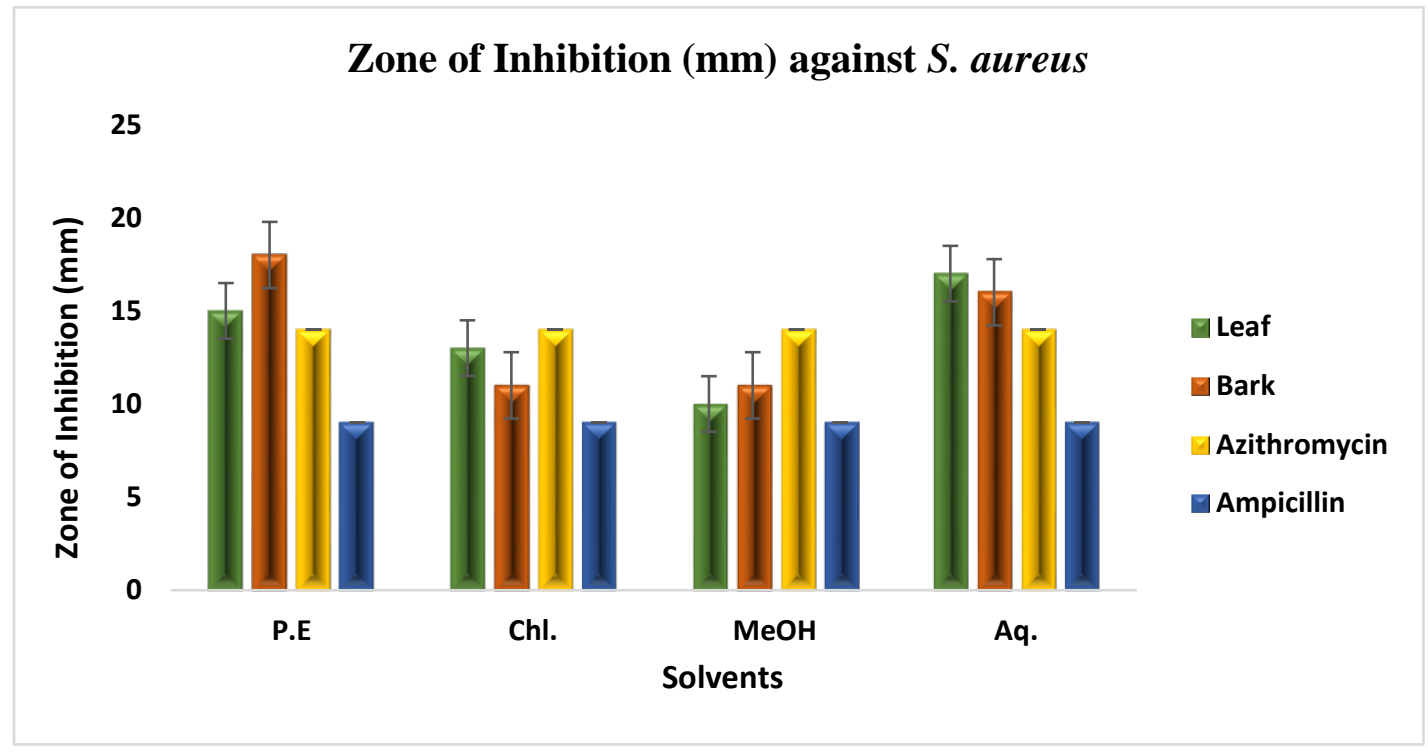

Figure 2. Graphical representation of the Zone of Inhibition against $S$. aureus

Table 5. The Zone of Inhibition produced by both parts of C.oppositifolia against the bacterial strains was documented in $\mathbf{m m}$

\begin{tabular}{|c|c|c|c|c|c|c|c|}
\hline \multirow{4}{*}{$\begin{array}{c}\text { Plant } \\
\text { Part }\end{array}$} & Solvents & S. aureus & E. coli & P. aeruginosa & K. pneumoniae & \multirow{2}{*}{ E. faecalis } & \multirow{2}{*}{ B. subtilis } \\
\cline { 2 - 8 } & & & & & $14 \pm 1.0$ & $16 \pm 2.0$ & $18 \pm 0.6$ \\
\hline & P. ether & $15 \pm 1.6$ & $14 \pm 0.5$ & $14 \pm 1.2$ & $14 \pm 0.7$ & $14 \pm 1.5$ & $12 \pm 0.3$ \\
\cline { 2 - 8 } & Chloroform & $13 \pm 0.8$ & $12 \pm 0.5$ & $12 \pm 0.5$ & $12 \pm 0.6$ & $11 \pm 0.7$ & $13 \pm 0.8$ \\
\cline { 2 - 8 } Leaf & Methanol & $10 \pm 0.8$ & $11 \pm 0.6$ & $10 \pm 0.3$ & $15 \pm 0.3$ & $15 \pm 0.5$ & $17 \pm 1$ \\
\cline { 2 - 8 } & Aqueous & $17 \pm 0.3$ & $17 \pm 0.3$ & $16 \pm 1.0$ & $17 \pm 2.0$ & $13 \pm 0.4$ & $15 \pm 0.3$ \\
\hline \multirow{3}{*}{ Bark } & P. ether & $18 \pm 0.8$ & $15 \pm 0.3$ & $18 \pm 2.2$ & $13 \pm 0.5$ & $12 \pm 0.4$ & $11 \pm 0.6$ \\
\cline { 2 - 8 } & Chloroform & $11 \pm 0.8$ & $10 \pm 0.3$ & $10 \pm 0.3$ & $10 \pm 1.0$ & $16 \pm 0.7$ & $10 \pm 0.5$ \\
\cline { 2 - 8 } & Methanol & $11 \pm 0.8$ & $11 \pm 0.5$ & $11 \pm 1.2$ & $11 \pm 0.6$ & $15 \pm 0.6$ & $17 \pm 0.3$ \\
\hline
\end{tabular}

Both leaf and bark extracts had showed marvelous potential against $E$. coli as well with the extracts in distilled waterdisplaying the record potential in response of the specific bacterial strain (Figure 3). The p. ether extracts of both parts had showed also better results against E. coli.
The leaf extract had exhibited the record potential against $P$. aeruginosaas well. With the petroleum ether being the most effective one. The aqueous extracts of bothparts of $C$. oppositifolia Smith had showed also satisfactory results against the particular bacterial strains (Figure 4). 


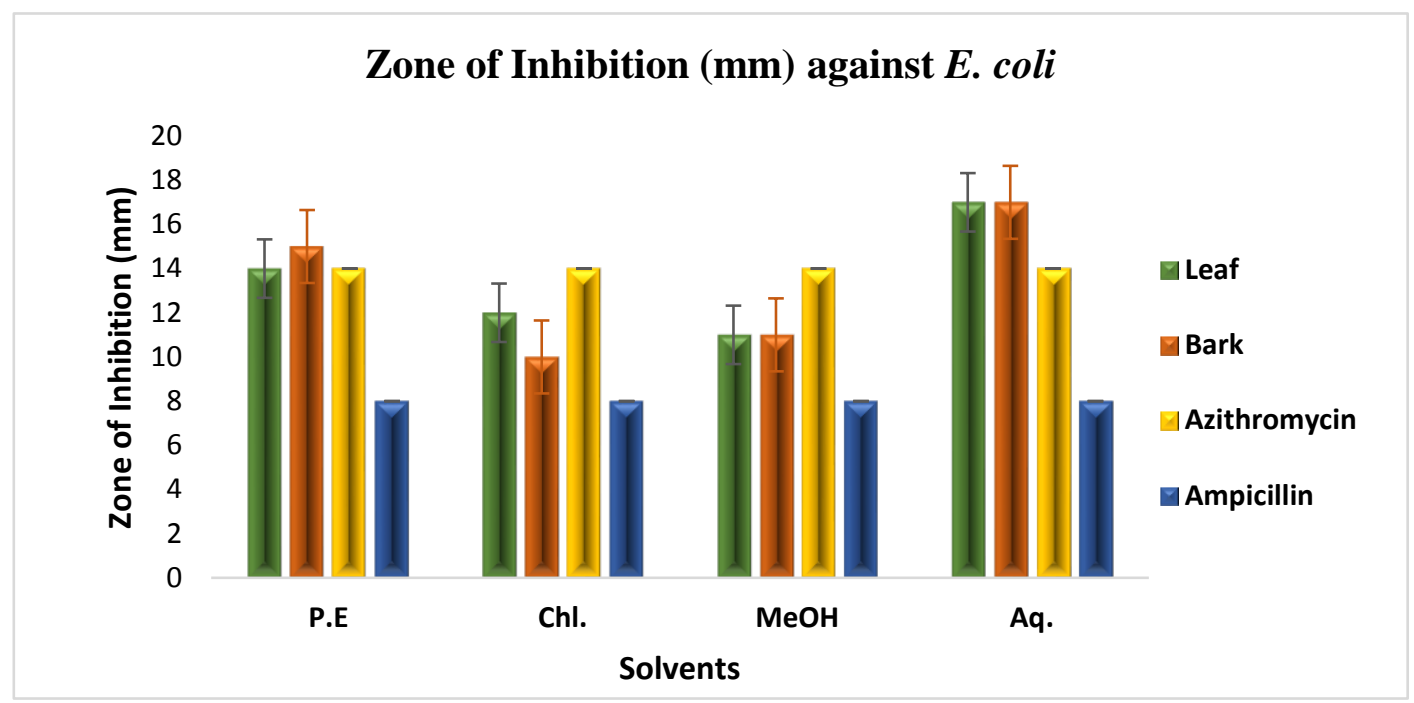

Figure 3. Graphical representation of the Zone of Inhibition against $E$. coli

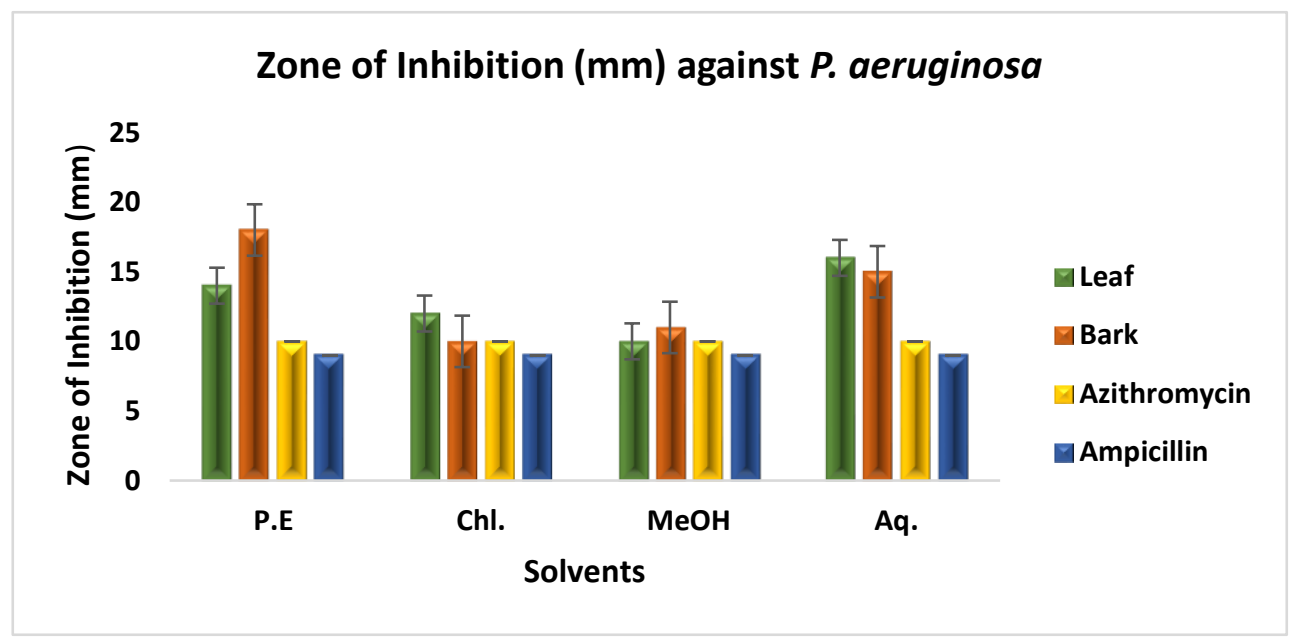

Figure 4. Graphical representation of the Zone of Inhibition against $P$. aeruginosa

Petroleum ether extract of bark $(17 \pm 2.0$ $\mathrm{mm})$ and aqueous extract of leaf $(15 \pm 0.3$ $\mathrm{mm}$ ) exhibited maximum potential against K. pneumoniae. Petroleum ether leaf extract and chloroform leaf extract had showed somewhat similar results against particular strains of bacteria i.e., $14 \pm 1.0$ $\mathrm{mm}$ and $14 \pm 0.7 \mathrm{~mm}$ respectively. The activity displayed by both parts was greater, as compared to antibiotic discs (Figure 5). The petroleum ether extract of leaf $(16 \pm 2.0$ $\mathrm{mm})$ and methanolic extract of bark $(16 \pm 0.7 \mathrm{~mm})$ showed maximum potential against E. faecalis. Aqueous extract of both leaf and bark of $C$. oppositifolia Smith exhibited somewhat similar and satisfactory results against $E$. faecalisi.e. $17 \pm 1 \mathrm{~mm}$ and $17 \pm 0.3 \mathrm{~mm}$. Whereas, chloroform bark extract and methanolic leaf extract shown minimal potential. The potential showed by both parts was better as compared to antibiotic discs which were used as standard (Figure 6).

The leaf extract had showed incredible activity against $B$. subtilis, as well with the extracts soaked in petroleum ether represented the maximum potential i.e., $18 \pm 0.7$ against the particular bacterial strain. The aqueous extracts of both parts had expressed significant activity against $B$. subtilis (Figure 7). 


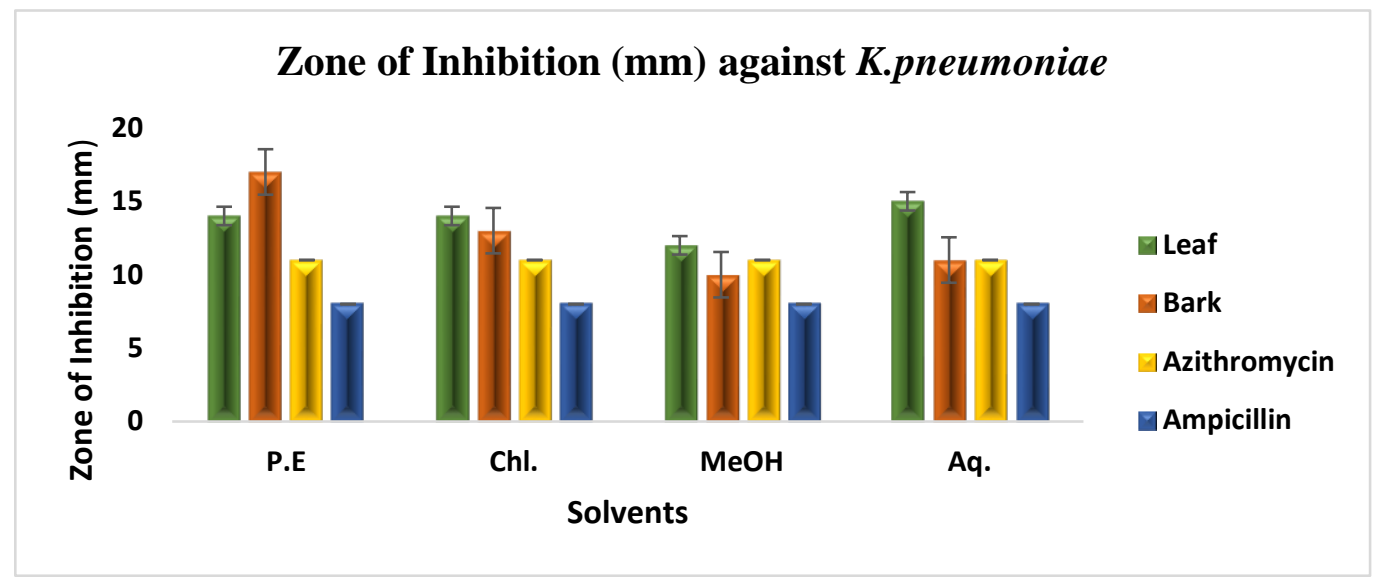

Figure 5. Graphical representation of the Zone of Inhibition against $K$. pneumonia

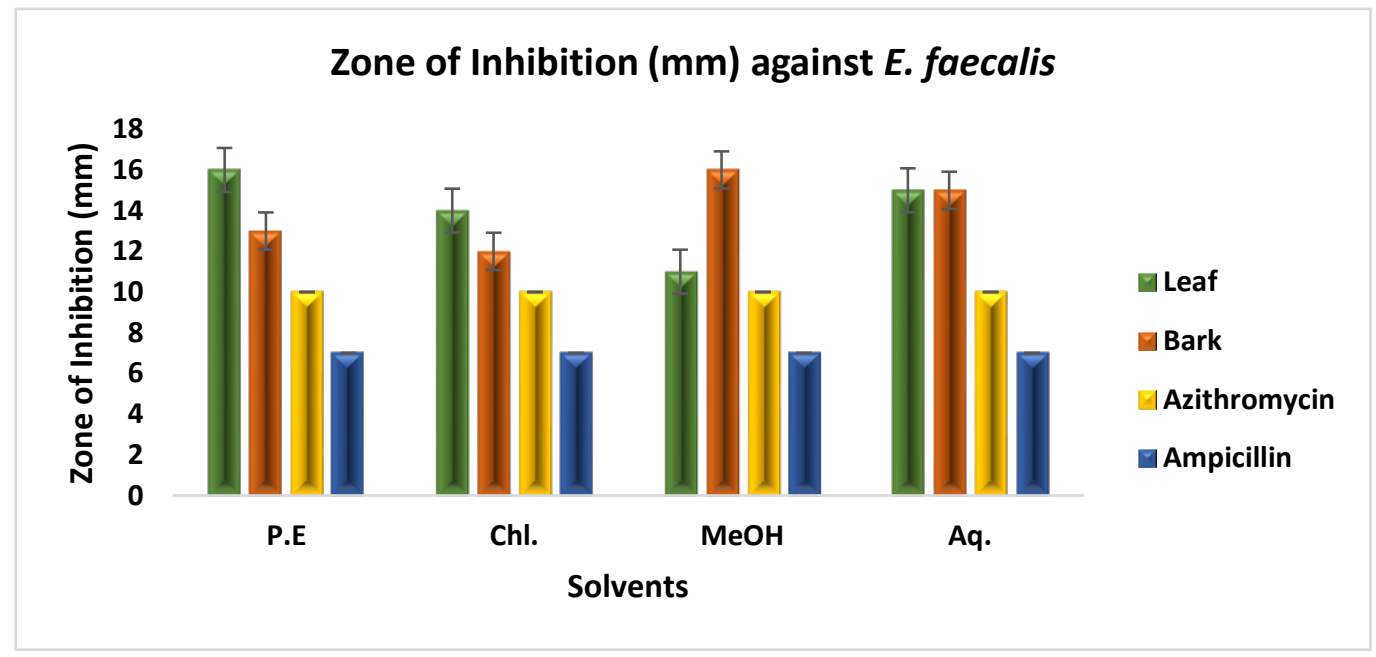

Figure 6. Graphical representation of the Zone of Inhibition against $E$. faecalis

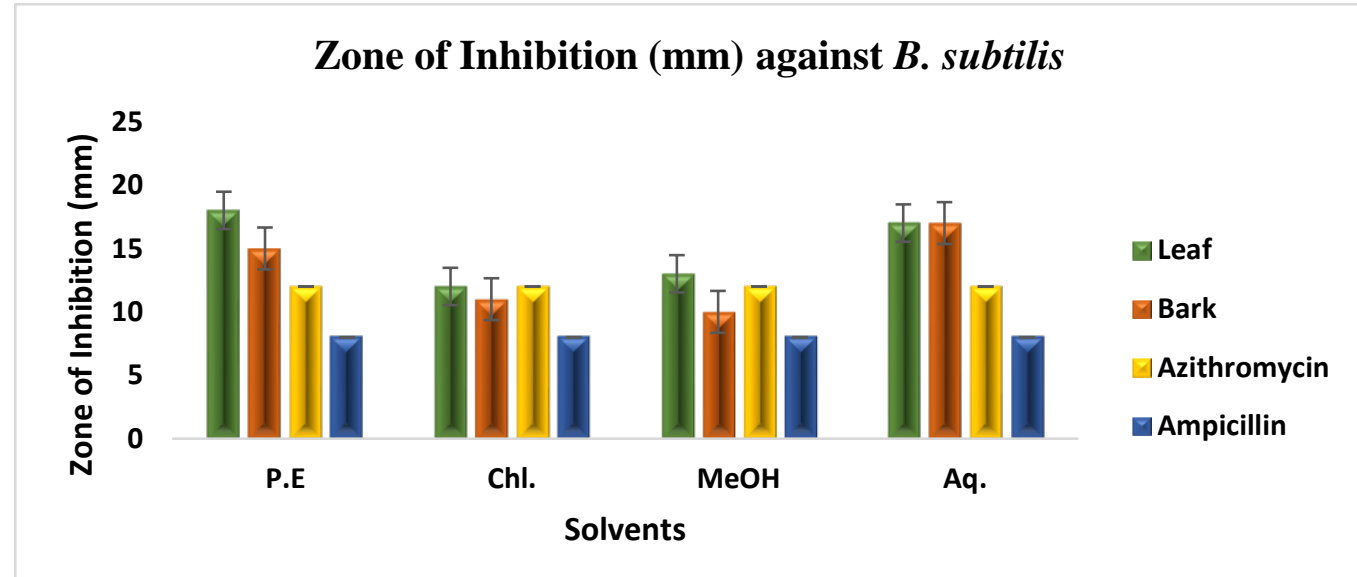

Figure 7. Graphical representation of the Zone of Inhibition against $B$. subtilis

MIC Assay

Themethanolic extracts were only employed for the MIC estimation of $C$. oppositifolia Smith. The leaf extract repressedthe growth of $S$. aureousefficientlywhile the bark extract showed maximum activity against $E$. coli (Table 6).

Methanolic extract inhibited growth of $S$. aureus very effectively and MIC value was $0.49 \pm 0.01$ at conc. of $0.9 \mathrm{mg} / \mathrm{mL}$ and $0.10 \pm 0.5$ at conc. of $0.8 \mathrm{mg} / \mathrm{mL}$ (Figure 8 ). 
The bark extract contained the significant potential against the all microbes, so we can say the bark extracts were more effective than leaf extracts. The bark and leaf extracts of C.oppositifoliaSmith were very effective against $E$. coli, their MIC values are $0.10 \pm 0.33$ and $0.09 \pm 0.3$ at conc. of 0.9 and 1 respectively (Figure 9).

Table 6. MIC values (mg/mL) exhibited by leaf and bark of $C$. oppositifolia against Grampositive and Gram-negative bacterial strains.

\begin{tabular}{|c|c|c|c|c|c|c|c|c|c|c|c|c|}
\hline \multirow{2}{*}{$\begin{array}{c}\text { Plant } \\
\text { Part }\end{array}$} & \multicolumn{2}{|c|}{ S. aureus } & \multicolumn{2}{c|}{ E. coli } & \multicolumn{2}{c|}{ P. aeruginosa } & \multicolumn{2}{c|}{$\begin{array}{c}\text { K. } \\
\text { pneumoniae }\end{array}$} & \multicolumn{2}{c|}{ E. faecalis } & \multicolumn{2}{c|}{ B. subtilis } \\
\cline { 2 - 24 } & Conc. & MIC & Conc. & MIC & Conc. & MIC & Conc. & MIC & Conc. & MIC & Conc. & MIC \\
\hline Leaf & 0.9 & $0.49 \pm 0.01$ & 0.9 & $\begin{array}{c}0.10 \pm \\
0.33\end{array}$ & 0.8 & $\begin{array}{c}0.13 \pm 0 . \\
7\end{array}$ & 0.9 & $\begin{array}{c}0.09 \pm \\
0.2\end{array}$ & 0.8 & $0.14 \pm 0.5$ & 0.7 & $0.10 \pm 0.3$ \\
\hline Bark & 0.8 & $0.10 \pm 0.5$ & 1 & $0.09 \pm 0.3$ & 0.9 & $\begin{array}{c}0.15 \pm 0 . \\
5\end{array}$ & 0.8 & $\begin{array}{c}0.10 \pm \\
0.3\end{array}$ & 0.8 & $0.12 \pm 0.7$ & 0.8 & $0.11 \pm 0.3$ \\
\hline
\end{tabular}

\section{MIC values against $S$. aureus}

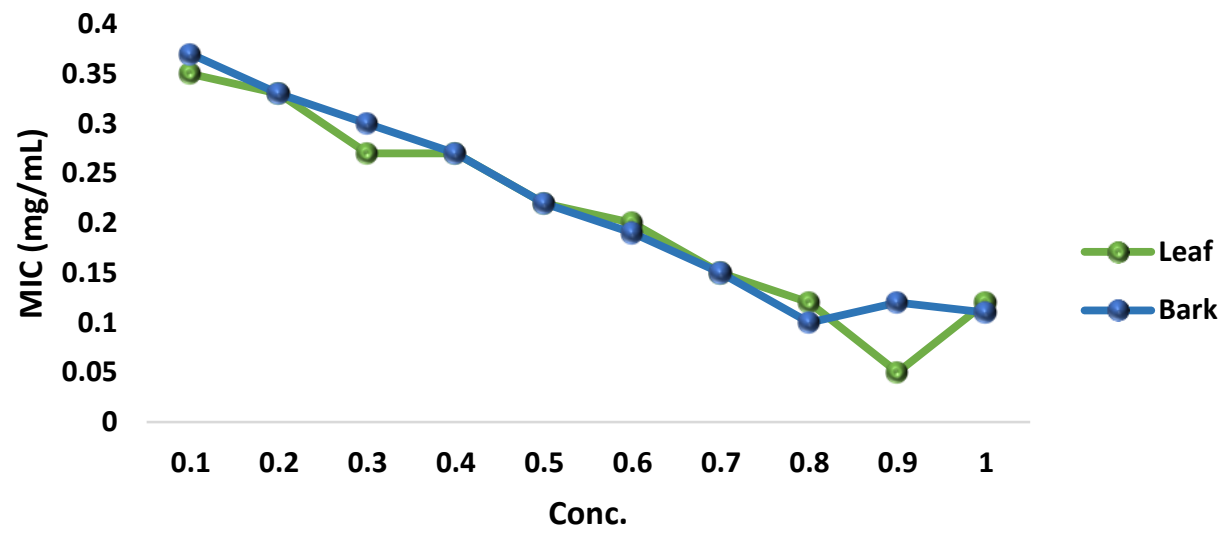

Figure 8. Graphical representation of the MIC values against $S$. aureus

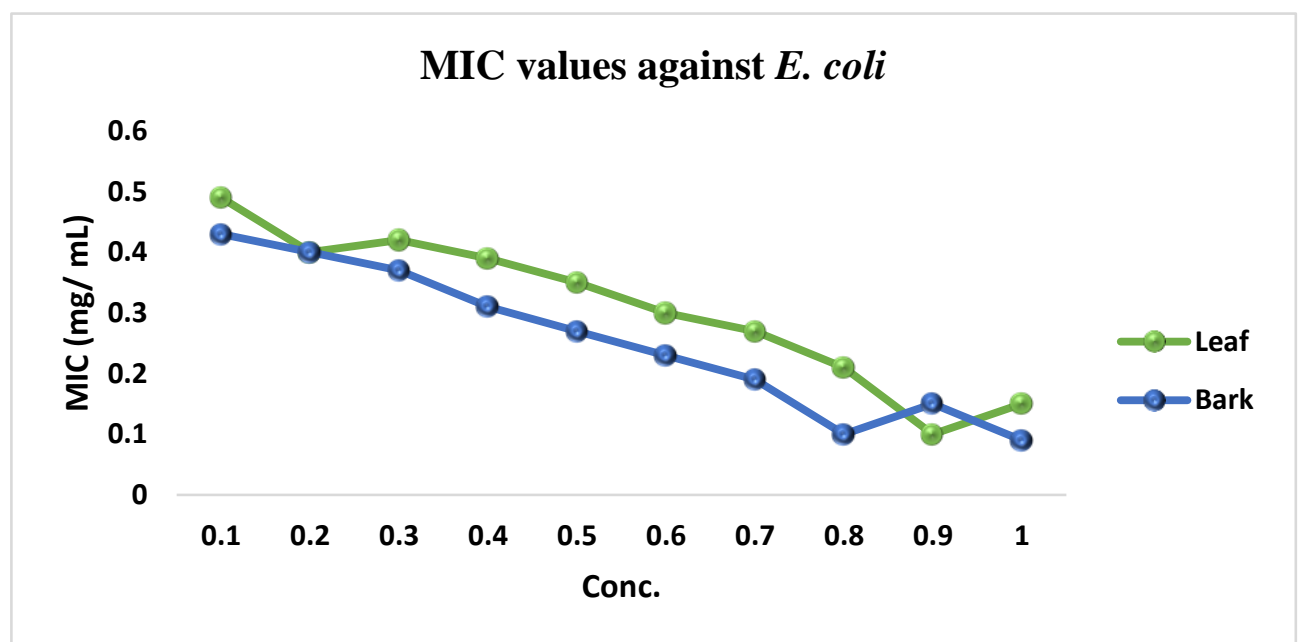

Figure 9. Graphical representation of the MIC values against $E$. coli 
The bark extract displayedsupreme potential in response of $P$. aeruginosa. The leaf extract were less effective than bark extract (Figure 10). MIC values estimated for both parts were $0.13 \pm 0.7$ at $0.81 \mathrm{mg} / \mathrm{mL}$ and $\quad 0.15 \pm 0.5$ at $0.9 \quad \mathrm{mg} / \mathrm{mL}$ correspondingly.

The $K$. pneumoniae was stated to be maximum delicate against the bark extract. When all methanolic extracts of $C$. oppositifoliaSmith during analysis were taken to consideration. The bark extract were more active than leaf extracts (Figure11). Actual MIC values estimated for both parts were $0.09 \pm 0.2$ at $0.9 \mathrm{mg} / \mathrm{mL}$ and $\quad 00.10 \pm 0.3$ at $0.8 \quad \mathrm{mg} / \mathrm{mL}$ correspondingly.
The bark extract showed maximum potential against E. faecalis then leaf extract. The bark extracts were extra effective as compared to leaf extracts in that case. MIC values estimated for both parts against $E$. faecalis were $0.14 \pm 0.5$ at 8.0 $\mathrm{mg} / \mathrm{mL}$ and $0.12 \pm 0.7$ at $8.0 \mathrm{mg} / \mathrm{mL}$ correspondingly (Figure 12).

The B. subtilis was stated to be the maximum resistant, against the methanolic extract of bark. Whereas, leaf extracts were extrareal than bark extracts. MIC values assessed for both parts of C.oppositifolia Smith against $B$. subtilis were $0.10 \pm 00.3$ at $0.7 \mathrm{mg} / \mathrm{mL}$ and $0.11 \pm 0.3$ at $0.8 \mathrm{mg} / \mathrm{mL}$ subsequently (Figure 13).

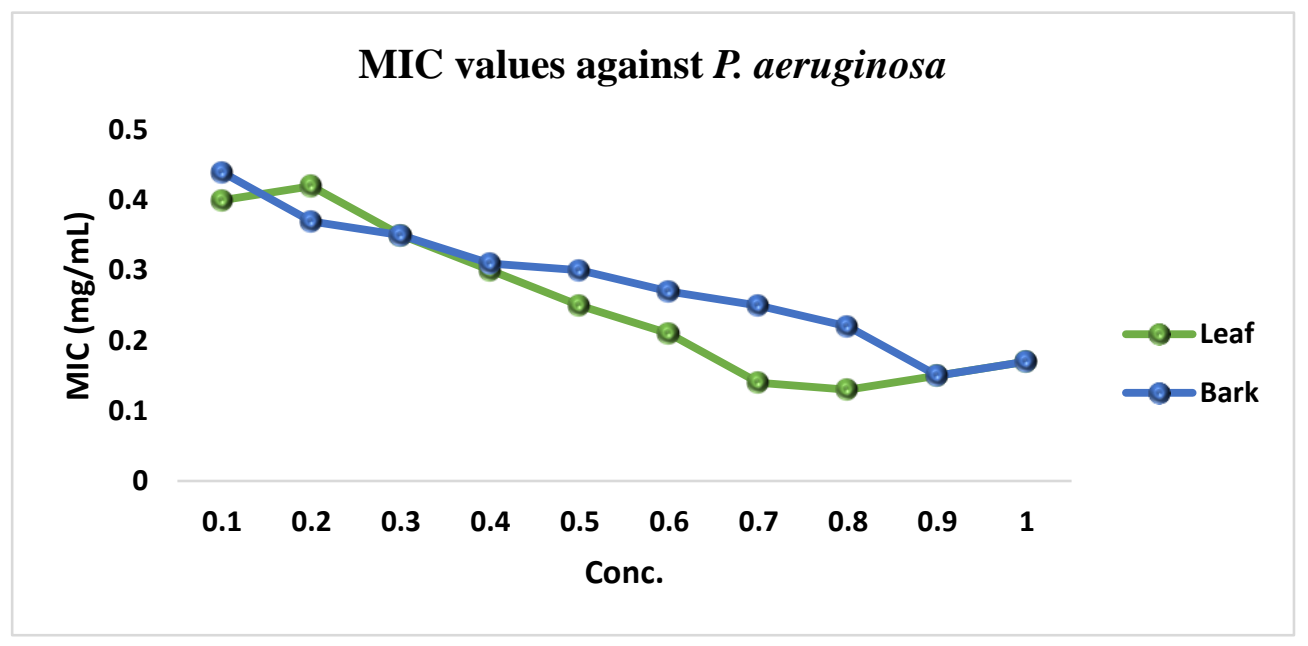

Figure 10. Graphical representation of the MIC values against $P$. aeruginosa

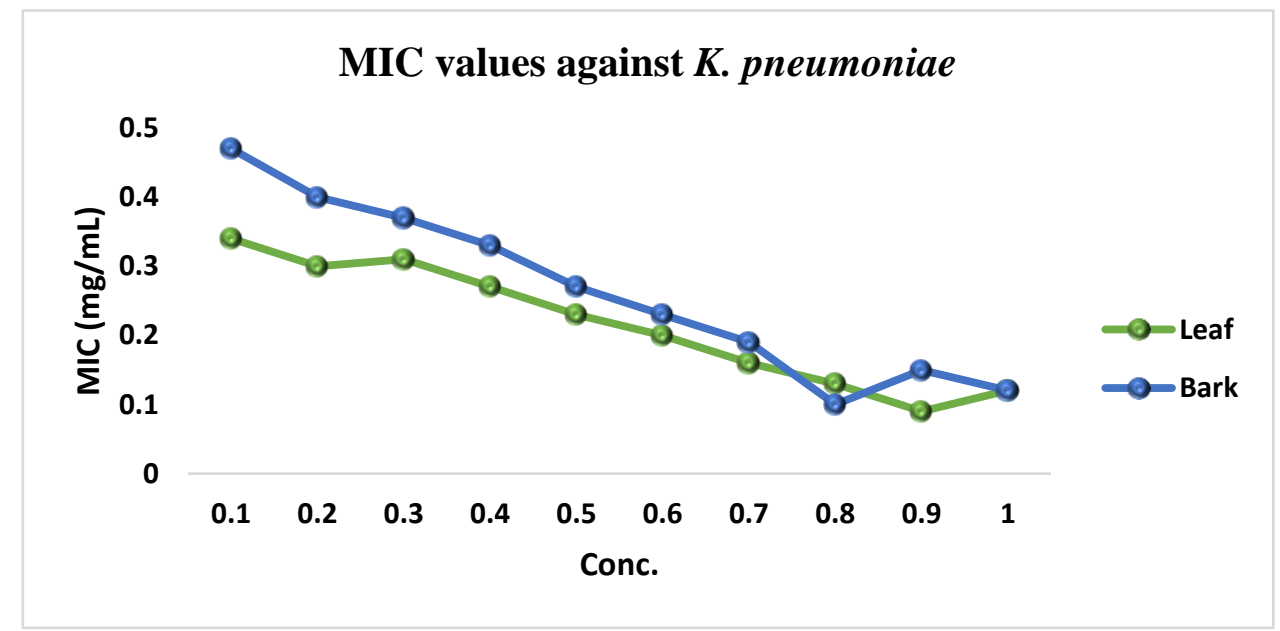

Figure 11. Graphical representation of the MIC values against $K$. pneumoniae 


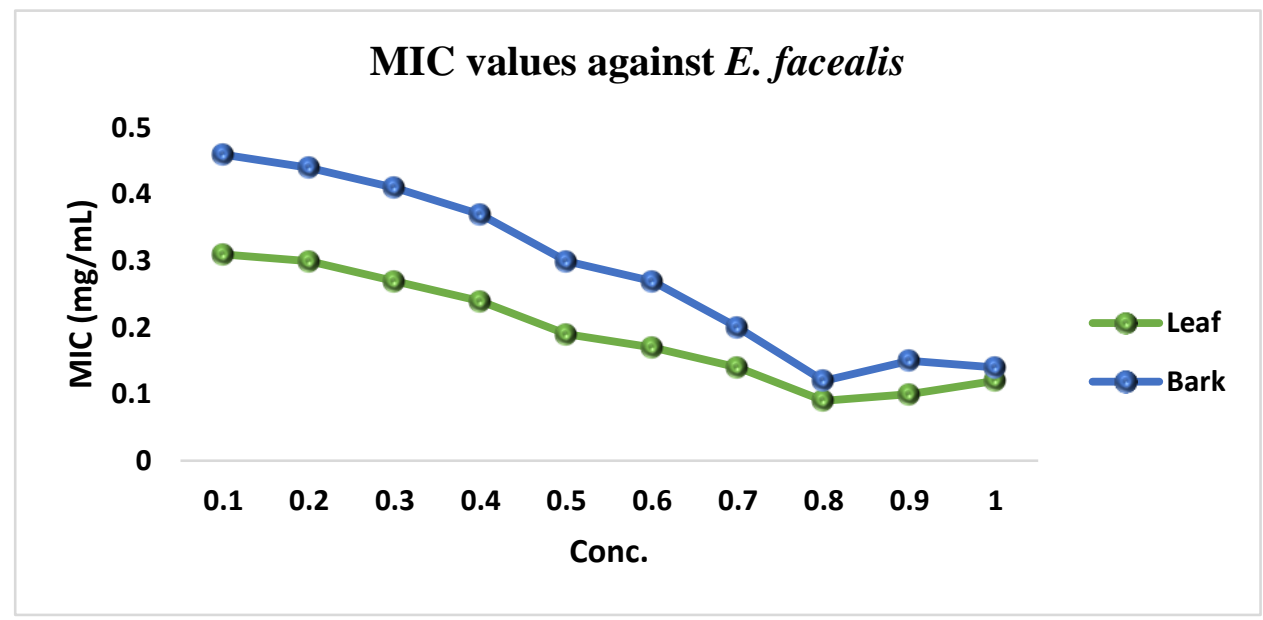

Figure 12. Graphical representation of the MIC values against $E$. faecalis

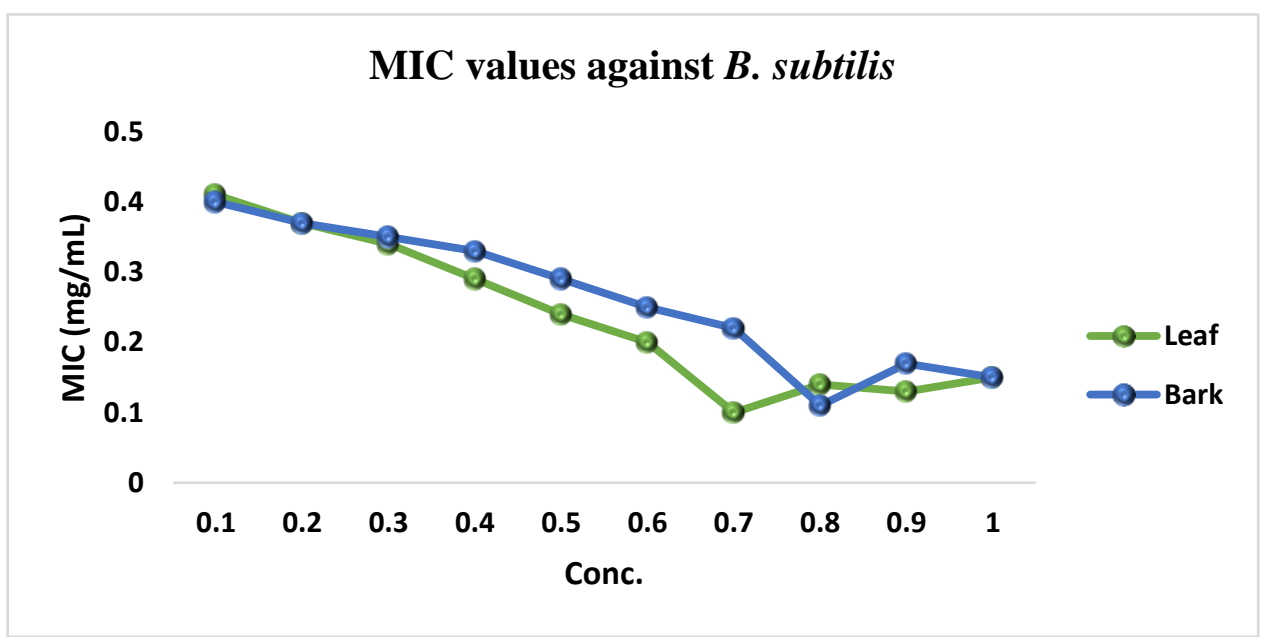

Figure 13. Graphical representation of the MIC values against $B$. subtilis

The antimycotic potential of the $C$. The A. oryzae strain had presented resistant oppositifolia Smith was estimated using two fungal strains i.e. A.niger and A.oryzae. The extracts had shown variable potential against these fungal strains with the extreme potency being showed by the leaf extracts soaked in distilled water. However, petroleum ether, chloroform and methanolic extracts had showed minimal potential against these fungal strains (Table 7).

The A. niger was additional sensitive near the plant extracts when equated to the $A$. oryzae. The supreme potential against the A. niger had showed by the aqueous extract of leaf. The petroleum ether extract of leaf had displayed less potential as compared to the petroleum extract of bark against the $A$. niger(Figure 14; Table 8). towards the plant extracts in comparison to A. niger. The supreme potential against the respective fungal strain was showed by the distilled water extract of both parts. The extract macerated in methanol had showed resistance compared to other extracts. The potential exhibited by the bark extract of $C$. oppositifolia Smith in chloroform was greater compared to leaf extract (Figure 15 $\& 16)$.

The extracts macerated in the methanol were also utilized for the MIC estimation. The leaf extract had exhibited maximum potential against $A$. niger with the MIC value $0.55 \pm 0.5$ at $0.9 \mathrm{mg} / \mathrm{mL}$ whereas, bark extract showed $0.50 \pm 0.5$ MIC value at $0.8 \mathrm{mg} / \mathrm{mL}$ (Table 8 ). 
Table 7. Zone of Inhibition exhibited by leaf and bark of $C$. oppositifolia Smith against fungal test organisms

\begin{tabular}{|c|c|c|c|}
\hline \multirow{3}{*}{ Plant Part } & \multirow{2}{*}{ Solvents } & \multicolumn{2}{|c|}{ Zone of Inhibition } \\
\cline { 2 - 4 } & P. ether & A.niger & A.oryzae \\
\hline \multirow{4}{*}{ Leaf } & Chloroform & $10 \pm 0.3$ & $15 \pm 0.3$ \\
\cline { 2 - 4 } & Methanol & $14 \pm 0.6$ & $16 \pm 0.6$ \\
\cline { 2 - 4 } & Aqueous & $14 \pm 0.6$ & $17 \pm 0.9$ \\
\cline { 2 - 4 } & P. ether & $28 \pm 0.3$ & $25 \pm 0.6$ \\
\hline \multirow{3}{*}{ Bark } & Chloroform & $14 \pm 0.3$ & $15 \pm 1.2$ \\
\cline { 2 - 4 } & Methanol & $15 \pm 0.9$ & $15 \pm 0.7$ \\
\cline { 2 - 4 } & Aqueous & $24 \pm 0.6$ & $20 \pm 1.2$ \\
\cline { 2 - 4 } & & & $24 \pm 1.5$ \\
\hline
\end{tabular}

Table 8. MIC values (mg/mL) exhibited by leaf and bark of $C$. oppositifoliaagainst fungal test organisms

\begin{tabular}{|c|c|c|c|c|}
\hline \multirow{2}{*}{$\begin{array}{c}\text { Plant } \\
\text { Part }\end{array}$} & \multicolumn{2}{|c|}{ A. niger } & \multicolumn{2}{c|}{ A. oryzae } \\
\cline { 2 - 5 } Leaf & Conc. & MIC & Conc. & MIC \\
\hline Bark & 0.9 & $0.55 \pm 0.5$ & 0.8 & $0.11 \pm 0.3$ \\
\hline
\end{tabular}

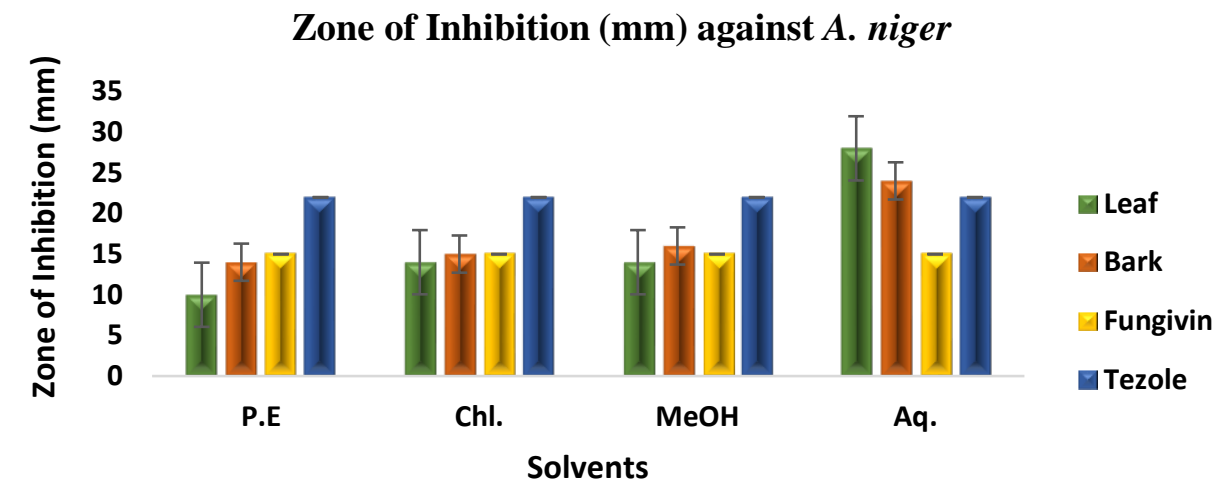

Figure 14. Graphical representation of the Zone of Inhibition against $A$. niger

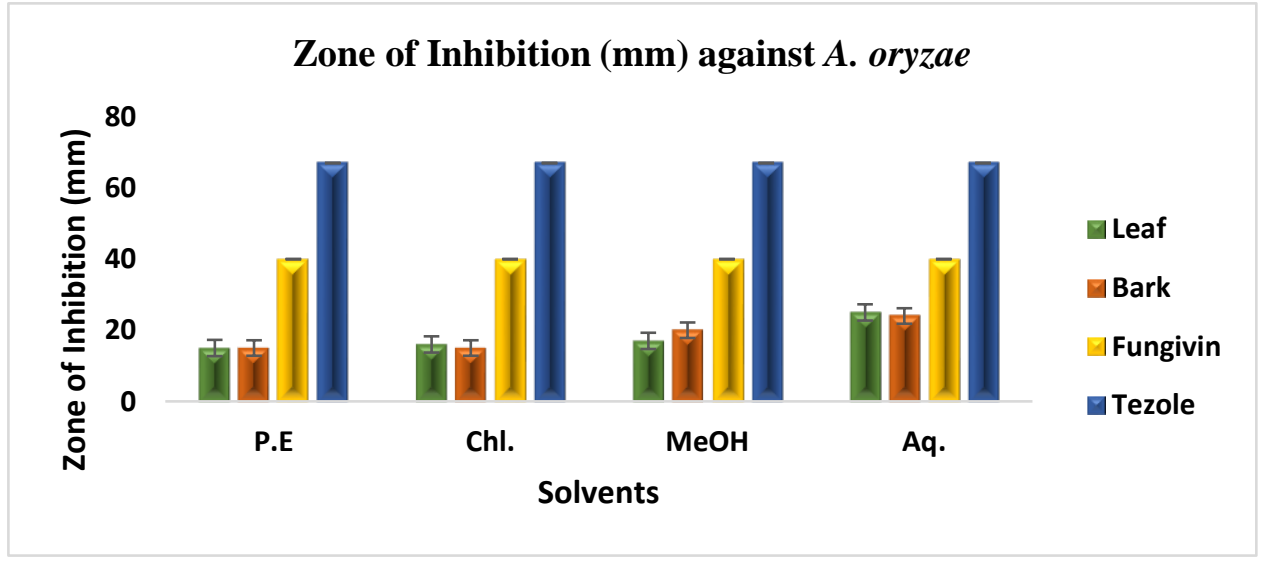

Figure 15. Graphical representation of the Zone of Inhibition against A. oryzae 


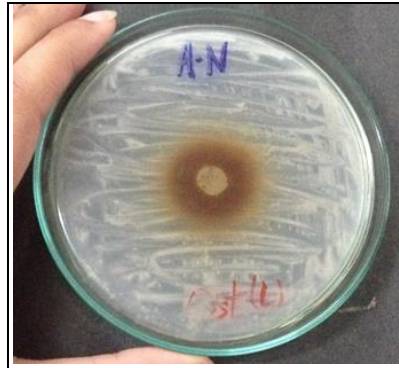

(a)

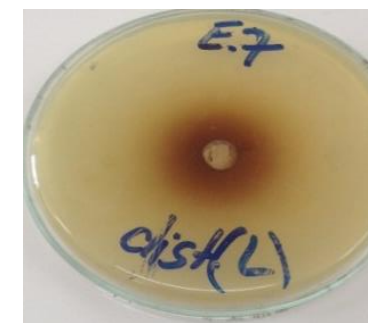

(e)

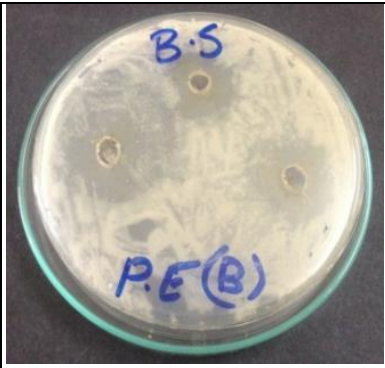

(b)

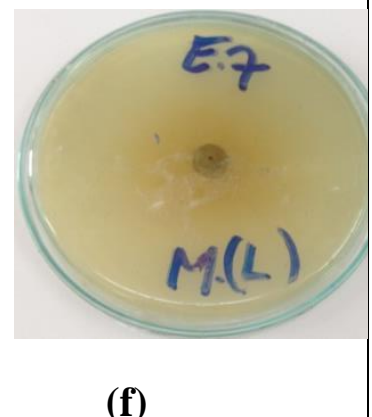

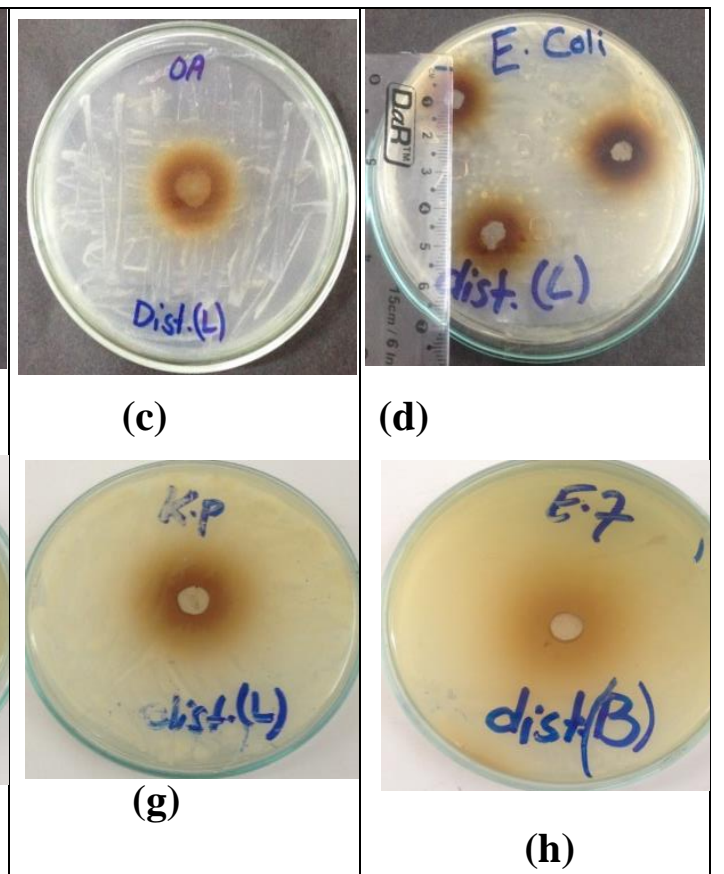

Figure 16. Zone of inhibition produced by: (a) Aqueous leaf extract against $A$. niger(b) P. ether bark extract against B. subtilis(c) Aqueous leaf extract against A. oryzae (d) Aqueous leaf extract against $E$. coli (e) Aqueous leaf extract against $E$. faecalis(f)MeOH leaf extract against $E$. faecalis(g) Aqueous leaf extract against $K$. pneumonia (h) Aqueous bark extract against $E$. faecalis

\section{Discussion}

The highest yield obtained from the leaf of C. oppossitifolia Smith was (17.13\%). The highest $\%$ extraction of yield of the leaf of C. oppossitifolia Smith was $7.73 \%$ which was nearly similar to the yield extract recorded by [17] during the assessment of some Indian plants with their ethno botanical values for their microbial potential. The lowest yield got in leaf extracts of C. oppossitifolia Smith was $2.6 \%$ in methanol which was in accord to the yield extract gained from the plant (leaf) extract of lamiaceae family i.e. Menthalongi folia (L.) Huds. reported by [18] during screening of some selected medicinal important plants extracts for In vitro antimicrobial activity.

The phytochemical screening of $C$. oppositi folia Smith showed the occurrence of alkaloids, steroids, terpenoids, saponins, glycosides, tannins, reducing sugar, flavonoids and cardiac glycosides in sufficient amount.

Two types of bacterial strains, i.e. gram positive and gram negative were used for investigation, in spite of their fundamental resemblances stated by [19].

The tendency of the antibacterial action shown by the extracts of $C$. oppositifolia Smith was nearly similar to that recorded by [20] on water and methanolic extracts from diffrent South African plants. The determined potential was given by leaf extract of plant.The bark extract had providing good to reasonable potential. However, the extracts of leaf and bark had showed almost alike activity with minute differences.

Within solvents overall, the petroleum ether extracts of $C$. oppositifolia Smith had extraordinary antibacterial potential in contradiction of all the organisms experienced during investigation. The maximum potential exhibited was $18 \pm 2.2$ $\mathrm{mm}$. Similar results were reported by [2] during analysis of antimicrobial and antioxidant activities of Chenopodium ambrosioides. This distinct activity had provided the evidence that the non-polar fractions i.e.,petroleum ether were vigorous 
in their activity compared to the relatively polar fractions i.e., methanol by [21].

The further amplification near the assessment of the antibacterial potential of C.oppositifolia Smith was providing by adopting microbroth dilution assay to estimate MIC value. And in this technique,methanolicextracts were only subjected to the MIC assay, because of its potential for the steady extraction of constituents got antibacterial potential. The MIC value of methanolic extracts of the plant under observation range from $0.09 \pm 0.2$ to $0.49 \pm 00.01 \mathrm{mg} / \mathrm{mL}$.

The MIC potential displayed by the $S$. aureus was estimated to be $\geq 0.10 \pm 0.5$ $\mathrm{mg} / \mathrm{mL}$. Furthermore, the MIC activity showed against $E$. coli was estimated to be $\geq$ $0.09 \pm 0.3$, against $P$. aeruginosa was $\geq$ $0.13 \pm 0.7$, against $K$. pneumoniae was $\geq$ $0.09 \pm 0.2$, against $E$. faecalis was $\geq 0.12 \pm 0.7$ and $\geq 0.10 \pm 0.3$ against $B$. subtilis. The MIC evaluations against the bacterial strains provided the evidence that the bark extract was more effective against $P$. aeruginosa followed by $S$. aureus. This results because of the fact that ,the bark was additional developed and ripe than leaves and may comprise some pigments and other composites which have been documented to inhibit with the antimicrobial activity of extracts stated by [22].

MIC efficiency for the fungal strain of the $A$. niger, was assessed to be within the range of $0.50 \pm 0.5$ to $0.55 \pm 0.5 \mathrm{mg} / \mathrm{mL}$, and $A$. oryzae was valued to be within the range of $0.11 \pm 0.3$ to $0.21 \pm 0.5 \mathrm{mg} / \mathrm{mL}$. So, it was clearly established that the potential of the plant against fungal strain was greater in $A$. nigerthan $A$. oryzaeparallel findings observed by [22] during investigation of antimicrobial activity of TamarindusindicaLinn.and [23] screened the antimicrobial and antioxidant activities ofCirsiumwallichiiDC.

\section{Conclusion}

On the basis of phytochemical and antimicrobial screening of Colebrookea oppositifolia Smith, the results showed that the leaf and bark extracts had provided excellent results against selected bacterial and fungal strains. The MIC assay had further provided the antimicrobial potential of plant's extracts. Thus, it can be concluded that all results are significant on the basis of increasing the concentration of the extracts. The antimicrobial activity is may be due to the presence of secondary metabolites i.e., alkaloids, flavonoids, tannins, sterols etc.

\section{Authors' contributions}

Conceived and designed the experiments: $\mathrm{M}$ Ajaib, Guide and wrote the article: S Abid, Performed the experiments: M Anjum, Q Noshad \& MA Iqbal, Analyzed the data: M Ajaib \& MF Sidduqui.

\section{References}

1. Kamran SH, Ahmad M, Shahwar D \&Ajaib M(2016). Anti-diabetic and antioxidant status of Loranthus pulverulentus obtained from two different hosts. Bangl J Pharmacol 11: 181-189.

2. Ajaib M, Hussain T, Farooq S \&Ashiq M (2016). Analysis of Antimicrobial and Antioxidant Activities of Chenopodiumambrosioides, An Ethnomedicinal Plant. J Chem 11.

3. Sharma S, Kelly TK \& Jones PA (2010). Epigenetics in cancer Carcinogenesis. 31: 27-36.

4. Doherty VF, Olaniran OO \& Kanife UC (2010). Antimicrobial activities of Aframomum melegueta (Alligator pepper). Inter J Bio 2: 126-131.

5. Ngwendson JN, Bedir E, Efange SMN, Okunji CO, Iwu MM, Schuster BG \& Khan IA (2003). Constituents of Peucedanumzenkeri seeds and their antimicrobial effects, Die PharmazieInter J PharmaceuSci58: 587-589.

6. W.H.O. (2010). World Health Organization, "World health statistics 2010," World Health Organization.

7. Djeussi DE, Noumedem JA, Seukep JA, Fankam AG, Voukeng IK, Tankeo SB, Nkuete AH \& Kuete V (2013). Antibacterial activities of selected edible plants extracts against multidrugresistant Gram-negative bacteria. BMC complem alter med13: 164. 
8. Burris HA, Tibbitts J, Holden SN, Sliwkowski MX \& Phillips GDL (2011). Trastuzumabemtansine (T-DM1): a novel agent for targeting HER2+ breast cancer. Clini breast cancer11: 275-282.

9. Ajaib M, Khan Z, Khan N \&Wahab M (2010). Ethnobotanical Studies on useful shrubs of district Kotli, Azad Jammu \& Kashmir, Pakistan. Pak J Bot 42: 14071415.

10. Kumar H, Kawai T \& Akira S (2011). Pathogen recognition by the innate immune system. Inter reviews immunolo 30: 16-34.

11. Subba B \&Basnet P (2014). Antimicrobial activity of some medicinal plants from east and central part of Nepal. Inter J Applied Sci. Biotech2: 88-92.

12. Ajaib M,Arooj T, Khan KM, Farid S, IshtiaqM,Perveen S \& Shah S. (2016). Phytochemical, Antimicrobial and Antioxidant Screening of Fruits,Bark and leaves of Lagerstroemia indica. $J$ Chem Soc Pak 38:538-545.

13. Ayoola GA, Coker H, Adesegun S, Bello A, Obaweya K, Ezennia E \& Atangbayila T (2008). Phytochemical Screening and Antioxidant Activities of Some Selected Medicinal Plants Used for Malaria Therapy in Southwestern Nigeria. Trop J Pharm Resea 7: 10191024.

14. Cruick-Shank R, Dugid JP, MariniononBP\& Swain RHA (1975). Screening of Some Greek Aromatic Plants for antioxidant Activity. Phytother Resea 17: 194-195.

15. Johansen DA $1940 . \quad$ Plant Microtechnique. MC-Graw-Hill Book Company, Inc. New York.
16. Murray PR, Baron EJ, Pfaller MA, Tenover FC, \&Yolke RH (1999). Manual of Clinical Microbiology, American Society for Microbiology (ASM), Washington, DC,USA, $7^{\text {th }}$ edition.

17. Parekh J \& Chanda S (2008). In vitro antifungal activity of methanol extracts of some Indian medicinal plants against pathogenic yeast and molds. Afr $J$ Biotech 7: 4349-4353.

18. Khond M, Bhosale JD, Arif T, Mandal TK, Padhi MM \&Dabur R (2009). Screening of Some Selected Medicinal Plants Extracts for In vitro Antimicrobial Activity. Middle- East J Sci Res 4: 271-278.

19. Ajaib M, Ashraf $Z$ \&Siddiqui MF (2017). Cocculus laurifolius, A Rich Antimicrobial, Antioxidant and Phytochemical Source. Pak J Bot 49: 337-344.

20. Rabe T \& Staden J (1997). Antibacterial activity of South African plant used for medicinal purposes. J Ethnopharmacol 56: 81-87.

21. Tadeg H, Mohammad E, Asres K \& Mariam TG (2005). Antimicrobial activities of some selected traditional Ethiopian medicinal plants used in the treatment of skin disorders. $J$ Ethnopharmacol 100: 168-106.

22. Doghari JH (2006). Antimicrobial Activity of Tamarindus indica Linn. Trop J Pharmaco Res 5: 597-603.

23. Hassan A, Ajaib M, Anjum M, Siddiqui SZ \& Malik NZ (2016). Investigation of Antimicrobial and Antioxidant Activities of Cirsium wallichii DC. Biologia (Pakistan) 62: 297-304. 